\title{
Heteronomy in the Arts Field: State Funding and British Arts Organizations ${ }^{1}$
}

British Journal of Sociology. Published online-first, DOI: 10.1111/1468-4446.12283.

Victoria D. Alexander

Goldsmiths, University of London

24 January 2017

Word Count: 9567

Keywords: Arts, Neoliberalism, Cultural Policy, United Kingdom, Cultural Fields, Autonomy/Heteronomy

\footnotetext{
Abstract

For Bourdieu, the field of cultural production is comprised of an autonomous and a heteronomous sector. A heteronomous sector is one that is interpenetrated by the commercial field. I discuss an arena that, until recently, was part of the relatively autonomous sector in the field of cultural production — the supported arts sector in the United Kingdom — and argue that it became more heteronomous, due to the penetration by the state. Heteronomy due to the commercial field is present but secondary to, and driven by, the actions of the state. Political parties' attempts to diffuse and legitimate a particular economic ideology have led to state demands that arts institutions adopt neoliberal business practices in exchange for funding. Government giving to the arts, previously at arms-length, proved to be a Faustian bargain that demanded significant repayment in the form of lost autonomy. Coercive pressures from the state, enacted over time, show how the domination of one field over another can occur, even when the domination is resisted.
} 


\section{Introduction}

In this paper, I make a theoretical argument about heteronomy in fields of action, drawing on Pierre Bourdieu's influential approach to cultural fields and to autonomy and heteronomy in them. I argue that Bourdieu's understanding of heteronomy in the field of cultural production as deriving from penetration by the commercial field needs to be expanded to include a consideration of penetration from the state. I illustrate this argument with a discussion of government support for the arts in the United Kingdom, specifically in relationship to neoliberalism, a politico-cultural belief that advocates monetary exchange and free markets as the best method to organize human activity. The supported arts sector includes institutions that house the visual or performing arts, such as art galleries, ${ }^{2}$ opera houses, non-profit theatres, symphony orchestras, ballet companies and the like that are, or potentially could be, funded by the public purse. In recent decades, the British state has required arts institutions in its supported arts sector to take on certain characteristics consistent with neoliberalism.

In the arts, especially the fine arts, a belief system revolving around art for art's sake explicitly contrasts with the neoliberal model. In the past (to oversimplify to some extent), non-profit arts institutions were more or less able to concentrate on artistic concerns. Today, they must explicitly attend to such business concerns as attendance figures and the financial costs of their activities. Attendance needs to increase. Costs need to shrink, unless income can expand. Today's arts institutions sell products to customers, where products include exhibitions and performances, but also goods and consumables sold in the shop and café. They compete in the leisure and tourism markets and contribute to the domestic economy, the balance of trade, and the growth of the creative sector. Most importantly, they use the tools of business management as means to achieve these goals. 
The valuing of a protected sphere of art-for-art's-sake is a relatively recent, western construction, tied to the defence of elite status boundaries (Bourdieu, 1984; 1993; 1996a; DiMaggio, 1982 a, b; 1987; Levine, 1988), which has been only partially achieved in that the fine arts are only relatively autonomous as compared to more commercial arts. Nevertheless, the changes in the supported art sector that I discuss in this paper represent a fundamental shift in the operations of arts institutions, towards a heteronomous, managerial focus. Aspects of this shift, which is necessarily complex, have been described, as 'privatization' (Boorsma, et al., 1998; Wu, 2002), ‘commodification' (Gray, 2000), ‘marketization’ (Alexander, 1999; 2008; Alexander et al., forthcoming; Mclean, 1997; Sandell and Janes, 2007), ‘democratization' (Ballé, 2002) and 'instrumentalization' (Gray, 2008; Toepler and Zimmer, 2002). ${ }^{3}$ While government ministers, 'hard-nosed' business people, and conservative economists might laud these changes, from within the arts world and from sympathetic academics these changes are a cause for concern or, at minimum, seen as a necessary evil (e.g. Appleyard, 1984; Hooper-Greenhill, 1988; Hewison, 1995; McCarthy et al, 2004; Mulcahy, 2004; Osborne, 1986; Zolberg, 2000).

How does neoliberalism 'get into' fields where other institutional logics previously held sway? The short answer-for the supported arts sector, at least-appears to be resource dependencies (Pfeffer and Salancik, 2003) or 'coercive' pressures (DiMaggio and Powell, 1983), as governments' changed requirements for the state funding on which cultural organizations were dependent. To illustrate this, I will follow the changes in the state's relationship to arts institutions over the last half-century. I also suggest that state-driven pressure to place neoliberal tools into new fields serves to legitimate the neoliberal discourse.

\section{Neoliberalism}


Neoliberalism is a political philosophy that identifies the competitive pursuit of selfinterest in a capitalist market freed from constraints as the foundation for individual freedom and the basis for organizing all aspects of human activity. It enshrines the value of free markets or 'an explicit preference for private over public control' (Centeno and Cohen, 2012: 317). Also called 'enterprise culture' (Heelas and Morris, 1992), neoliberalism emphasizes three key principles: the efficiency of markets, the liberty of individuals, and the noninterventionism of the state. It is a politico-cultural viewpoint, a power-producing philosophy that reproduces dominant privilege, as many scholars have argued (Bourdieu, 1995; 1989a, b; 2003; Bourdieu and Wacquant, 1999; 2001; Centeno and Cohen, 2012; Chang, 2010; Crouch, 2011; Evans and Sewell, 2013; Frank, 2000; McGuigan, 2005; 2009; 2016). Though 'noninterventionist', the state does have a role: to enact an institutional framework that supports neoliberal practices. As Harvey (2005: 2) put it, 'if markets do not exist...then they must be created, by state action if necessary.'

For the past thirty-five years or so, the UK government has worked to embed such market arrangements in many policy areas, including the cultural sector. A crucial part of this is neatly packaged in the phrase 'value for money', which suggests that government funds must be spent efficiently, in economic terms. The supported arts sector, along with other public services, has become accountable for its use of 'the taxpayers' money'. Value is demonstrated through measurable outputs ('performance indicators') that are assessed in monetary terms against inputs (i.e. funding levels). The number of museum visitors ('customers') or the social diversity of audiences for a performance (the 'service provided') are such indicators. Moreover, neoliberalism invariably employs the language of business, especially that of marketing. Managers of public services, therefore, are required to take up commercial approaches and practices. Revenue enhancement is another essential aspect of neoliberalism in the public sector. In the arts, this can be achieved through private 
sponsorship or patronage and through earned income such as ticket sales or admission charges or revenue from sales in gift shops and cafés.

Bourdieu wrote extensively about neoliberalism, as I will discuss below. But I first set out the key issue addressed by the paper: Bourdieu's ideas on autonomy and heteronomy in the field of cultural production. I will then sketch out how changes in the British supported arts sector, enacted through funding, represent a reduction in its autonomy.

\section{Bourdieu and Fields}

Central to the argument here are Bourdieu's ideas on fields. Bourdieu (e.g. 1993, 1996b) described society as consisting of a series of arenas, or 'fields' in which individuals vie for status and control, or in other words, where people struggle for the cultural, symbolic, social, and economic capital at stake in the field. These arenas can be overlapping, but are often distinct, and different fields may be homologous (i.e., have similar structures). Overarching the various fields of action is the 'field of power': an arena in which elites compete for power and for hegemonic control over subordinate classes.

An important part of Bourdieu's work, notably in Distinction (1984), is his argument that elites not only compete with each other for control, but they also seek to legitimate their own position. This allows elites to appear as 'naturally' superior. For instance, taste in art (aesthetic judgment) may appear to be a neutral, personal choice, but in fact, Bourdieu argues, it is connected to a person's position in the social order, and shaped by it (through habitus). Moreover, taste for the 'consecrated' forms of art reproduces the inequality that enabled it in the first place. In Bourdieu's words: 
At stake in every struggle over art there is also the imposition of an art of living, that is, the transmutation of an arbitrary way of living into the legitimate way of life which casts every other way of living into arbitrariness. (1984: 56-7)

A preference for legitimated cultural forms is 'an affirmation of the superiority' of those who prefer them, which is why 'art and cultural consumption are predisposed...to fulfil a social function of legitimating social differences' (1984: 7). In other words, the dominant class positions its culture as 'naturally' the best. It is not only in taste and cultural consumption that the dominant class seeks legitimation, however. Elites also seek to legitimate their political and economic philosophies as well, neoliberalism being the case in point (e.g. Bourdieu, 1995: 10-11, 223-232; 1996b; 1998a).

\section{The Field of Cultural Production}

Bourdieu described the cultural field (or fields) ${ }^{4}$ as having autonomous and heteronomous poles $(1993,1996 a)$. In the former, as for example the literary world of Flaubert or in Symbolist poetry, the arts are rich with cultural capital, but relatively, or even literally, impoverished with respect to economic capital. Producers vie with each other for varied symbolic capital such as prestige, with those showing the least interest in anything but the art itself gaining the most status. Thus, cultural and symbolic capital are the stakes in the autonomous sphere.

In the arts, Bourdieu referred to the autonomous pole of cultural production as the field of 'restricted production', which focuses on art for art's sake. The audience for such works is relatively small ('restricted') and producers produce mainly for other producers, not for broader or mass audiences. This autonomous sphere is supported by a 'pure' gaze, or more accurately, the claims viewers make that their gaze is pure. Such an 'aesthetic' gaze is 
constituted as 'capable of considering the work of art in and for itself' (1993: 36). For Bourdieu, the autonomous sphere is found in the fine arts.

Autonomous fields represent 'the economic world reversed' (see Bourdieu, 1993: Chapter 1). Such fields are anti-economic because they shun (or profess to shun) economic profits and short-term gains. This lack of interest in financial gains, the 'disinterestedness' of producers in anything but the art itself is a defining feature of autonomous fields. They are '[f]ounded on the obligatory recognition of the values of disinterestedness and on the denigration of the "economy" (of the "commercial")' and they are 'oriented to the accumulation of symbolic capital' (Bourdieu 1996a: 142). Bourdieu (1993: 39) explained how this creates a reversal of the economic world:

in the most perfectly autonomous sector of the field of cultural production, where the only audience aimed at is other producers (as with Symbolist poetry), the economy of practices is based, as in a generalized game of 'loser wins', on a systematic inversion of the fundamental principles of all ordinary economies: that of business (it excludes the pursuit of profit and does not guarantee any sort of correspondence between investments and monetary gains)...

In contrast, Bourdieu defined heteronomous art fields as those that are interpenetrated by commercial fields. They do not garner as much status as the 'pure', autonomous arts, but they have a greater ability to earn money. Bourdieu described this as the field of 'large scale production'. Heteronomous arts range from the 'Bourgeois arts', which sell to and gain consecration from more privileged social classes, to lowbrow, commercial works, or 'Industrial arts'. For Bourdieu, heteronomous fields in cultural production can encompass 
the fine arts as well as the popular arts. This is because the autonomy or heteronomy has to do with the relationship among fields; it is not a property of genres of art.

Bourdieu also recognized that an important component of the field is the apparatus that supports it. With respect to the autonomous arts as a subfield of cultural production, Johnson (1993: 15) notes,

The symbolic power of this sub-field's products is sustained by a vast social apparatus encompassing museums, galleries, libraries, the educational system, literary and art histories, centres for the performing arts and so forth.

Bourdieu (1993) saw art museums as instruments of the 'pure gaze' in that this gaze is 'linked to the institution of the work of art as an object of contemplation, with the creation of...museums, and the parallel development of a corps of professionals appointed to conserve the work of art, both materially and symbolically' (p. 36, emphasis in the original). The museum is 'consecrated and consecrating' ( $\mathrm{p}$. 257), and contributes to a 'discourse about a work [that] is not a mere accompaniment, intended to assist its perception and appreciation, but a stage in the production of the work, of its meaning and value' (p. 110). Other institutions of fine arts are similarly consecrated and consecrating.

My focus is on arts institutions, on the social apparatus, rather than on artistic producers themselves. This apparatus, nevertheless, actually produces culture not just in producing meaning and value in the work of art, but also through the production of exhibitions and performances. Attending an exhibition or a performance is the main way most people actually experience the fine arts. Bourdieu (1993:40) suggested that 'The literary and artistic world is so ordered that those who enter it have an interest in disinterestedness'. Through this disinterest, arts organizations claim the cultural and symbolic capital that is 
inherent in an autonomous field of art. Arts institutions have thus historically produced an anti-economic, disinterested stance as a core aspect of their operations.

\section{Heteronomy and the State}

Bourdieu (1993: 37) argued that the field of cultural production is embedded within the field of power. While the autonomous pole is relatively free from both political and economic penetration by the field of power, Bourdieu described heteronomy (in the field of large-scale production and also in the interpenetration that exists in the autonomous cultural sector) only in terms of commercial influence. He tended to neglect the interpenetration of the political aspects of the field of power. I suggest that a very important change in the fine arts is that the relatively autonomous pole of the arts field has not only become more interpenetrated by the commercial field, the arts field has also become interpenetrated by the state. The nation-state is decreasing the autonomy of the field of cultural production, in concert with but separate from, the heteronomy that obtains due to the market.

The potential for heteronomy from the sphere of politics is entirely consistent with Bourdieu's model of the field of cultural production. Indeed, in places he seemed to suggest that politics does penetrate the cultural field. For instance, Bourdieu (1998a: 38) wrote, 'It is in the realm of symbolic production that the grip of the state is felt most powerfully'. But here Bourdieu was referring to academic and juridical writing, not the fine arts. Moreover, Bourdieu did not develop this idea in The Field of Cultural Production (1993) or The Rules of Art (1996a), and heteronomous fields have been associated with commercial influence, rather than state influence.

\section{The Faustian Bargain}


How is it, then, that the state has launched a direct assault on the elite aesthetics of the 'pure gaze', and won the assent — or at least the acceptance — of neoliberal ideals by the professionals in charge of arts organizations that support high culture? To answer this question, I will give an account of the 'Faustian bargain' made between arts institutions and the state. This is based on policy research and 20 years of observation of the UK supported art sector (sources on each era discussed are reported in footnotes).

According to legend, Faust was a successful scholar but one ambitious for greater knowledge and worldly pleasures. In his bargain with the devil, he traded his soul for Mephistopheles' assistance to attain his wishes. In the Faustian bargain between the arts and the British state, money from the state initially provided commissions, performances and exhibitions of great art. State funding seemed beneficial, and safeguards were put in place to protect against certain dangers, such as party-political influence and the constrained or propagandizing state culture that can emerge from central ministries. However, state funding contained obligations, and these obligations, once benign — or, more accurately, previously consistent with the priorities of the arts world — changed with the ruling political philosophies. An important change, discussed below, occurred with the 1979 election that made Margaret Thatcher Prime Minister. Thatcher once said, 'Economics is the method, but the object is to change the soul' (quoted in Harvey 2005: 23).

In the UK, state funding for the arts started in earnest with a wartime agency, the Council for the Encouragement of Music and the Arts (CEMA), set up in 1940 to raise spirits on the home front. ${ }^{5}$ Initially, it supported somewhat middlebrow programs. However, when John Maynard Keynes took the helm in 1941, the artistic content supported by CEMA moved sharply to the highbrow. He was reportedly 'not a man for wandering minstrels and amateur theatricals. He believed in excellence' (Wu, 2002: 34). The fact that Lord Keynes, a representative of the 'cultured' elite, shifted the CEMA funds under his control from easily 
accessible 'art for the people' to the fine arts 'exclusively' would not be a surprise to Bourdieu.

After the war, in 1946, the British government established the Arts Council of Great Britain. At that time, state funding of the arts was largely seen as beneficial to the fine arts.

A widely shared assumption of the time was that 'authentic,' 'high' ... culture needed to be protected, maintained and ... disseminated against an ever more dominant and meretricious mass culture. (McGuigan, 2009: 153)

From the very beginning, the Arts Council carried tensions between support for an 'excellent' quality of art and an effort to disseminate art to people from different regions or walks of life. This was often phrased as a debate between 'raising' (of standards, even if this meant a focus on London) or 'spreading' (distributing works across the country). However, as DiMaggio (1982a, b) has argued, for art to be seen widely as status-enhancing 'high culture', it must be made available (though education), but only partially, to non-elite groups in society- that is, it must be spread at least somewhat. Thus although they may stand in opposition, both aims, excellence in art and reaching broader audiences, fit the arts world's own goals.

The Arts Council was, importantly, set up with an 'arms-length' arrangement. The Treasury allocated funds to the Council, and the Council, independently from Government, decided how to spend them. This arrangement was put in place to protect the arts from interference by political parties. From the perspective of the arts world, this was beneficial because the Council was, to a very great extent, autonomous. The Arts Council responded to initiatives from the arts world rather than devising its own initiatives. Along with the armslength principle, this was a strategy to avoid an 'official' art arising from the state. All in all, in the early days of the Arts Council, the art world was successful in safeguarding its 
autonomy even as it gained state funding. And over time, arts institutions came to see the Arts Council as a largely benign source of largesse.

In 1979 when she became Prime Minister, Thatcher, a bearer of neoliberal ideology, privatized many industries (i.e. sold publicly run services to private companies) and changed the relationship between the state and the state-supported organizations that were not privatized. In the arts, Thatcher's government added various requirements that accompanied any funding, such that arts organizations needed to show 'value for money' and needed to be auditable. ${ }^{6}$ Arts organizations that were regularly funded by the Arts Council were required to follow 'best practice' in arts management: to prepare business plans and submit to management reviews. National museums also were required to prepare forward planning and strategy documents and to be audited for efficiency and effectiveness in meeting targets.

Thatcher, crucially, cut funding to the arts, defunding some arts organizations entirely. Reduced funding posed challenges to arts organizations where budgets could no longer support programs and staffing costs made possible by more generous government funding. To maintain the accustomed levels of programing, arts organizations had to seek supplemental funding elsewhere, through sponsorship or through earned income generated through 'better management'. Thatcher also put in place incentives for corporations to fund arts organizations. Corporations also required arts organizations to be accountable for the funds that were offered (Alexander, 1996a, b; $c f$. Trnka and Trundle, 2014).

Subsequent governments have continued these policies, although varying them in some particulars. ${ }^{7}$ Conservative Prime Minister John Major, elected in 1990, maintained most of Thatcher's policies toward the arts. The New Labour party, which came into power in 1997 with Prime Minister Tony Blair, seemed to promise dramatic shifts in policy across all sectors. However, the 'new' in New Labour meant a more centrist and business-friendly party, and while Blair increased funding to the arts sector, he nevertheless adopted neoliberal 
policies towards the arts that had notable affinities to Thatcher's. Requirements for auditing, accountability, and efficient administration continued for arts organizations funded by the state.

Moreover, Blair also asked the arts to contribute to non-arts policy objectives. Early in his tenure, his government required arts organizations to contribute to his 'social inclusion' and 'neighbourhood renewal' agendas. In other words, arts organizations were asked to increase the diversity of their audiences and to influence and inspire not only individuals but neighbourhoods as well, particularly disadvantaged ones. That the arts could contribute to these extrinsic policy areas underpinned the justification for continued state support of the arts. Later in Blair's tenure, the arts were valued, in policy terms, by their ability to provide 'economic impact', for instance, by attracting tourists and supporting the for-profit creative sector. As McGuigan (2005: 238) notes:

A distinctive yet seldom mentioned feature of neo-liberal development is to translate issues of social policy into questions of cultural policy. And, in its turn, cultural policy ceases to be specifically about culture at all. The predominant rationale for cultural policy today is economic, in terms of competitiveness and regeneration, and, to a lesser extent, social, as an implausible palliative to exclusion and poverty. ${ }^{8}$

The Labour Prime Minister Gordon Brown replaced Blair in 2007. During his short term in office, he continued a largely instrumental and neoliberal approach to the arts.

In 2010, the UK General Election failed to return a majority to any party. As a result, a coalition government between David Cameron (Conservative) and Nick Clegg (Liberal Democrat) was formed. This government made dramatic changes in many policy areas, often going much further than Thatcher with respect to funding cuts and privatization. In the arts 
sphere, the Coalition acted to further a 'philanthropy agenda' (Cabinet Office, 2010), ${ }^{9}$ as part of the 'Big Society'. (The 'Big Society', part of the Conservative Party's manifesto, promoted voluntarism as complementary to a shrinking state.) The Coalition hoped to encourage private philanthropy in place of public funding. As with Thatcher, these changes were accompanied by funding cuts for the Department for Media and Sport (DCMS) and the Arts Councils. And from 2015, austerity increased under Cameron's Conservative (only) government. $^{10}$

To sum up: Arts organizations entered into exchanges with the state, and later, through the state's influence, with corporations. Previously, state funding for the arts worked to benefit elites in the arts world as well as those in the political realm. Public funding provided rewards for the state, through the production of public cultural goods that provided a cultural legitimation for the nation-state and its governments. And it provided the ability for arts institutions, functioning relatively autonomously from the market and from political influence, to produce art for both public good and private distinction. Arts funding by the British government before 1979 protected arts institutions from both the marketplace and from the state itself through the arms-length principle that granted autonomy (from the state) to the government agencies that funded the arts. Indeed, these agencies were part of the autonomous art world. Since Thatcher, however, the system has shifted. The creation of an exhibition or performance, by itself, is no longer a sufficient return for state (or corporate) funds. A crucial part of recent state funding is that arts organizations must give evidence of being well managed, professional, and accountable (c.f. Power, 1997), through the adoption of particular management styles. Today's funding pushes arts intuitions into the arms of the market as the state has asserted control over its funding agencies, and arts organizations must take on a neoliberal calculus where the arts are valued by their extrinsic outcomes and organizations are run with business-world logic and tools. ${ }^{11}$ 
The autonomous status of art has been challenged as arts institutions come to be influenced not only by the commercial field but also by the state. The effects of such a change in arts institutions are extensive. ${ }^{12}$ For instance, Wu (2000) showed how corporate sponsorship, which was explicitly encouraged by the state, led to the appearance of corporate logos in art galleries and the use of fine arts for advertising purposes. Macdonald (2002) discussed how museums began to market themselves in the 1980s in a direct response to state pressures for measurable outcomes, such as increased visitor numbers. At this time, the Victoria and Albert Museum (V\&A) produced infamous advertising posters with the caption, 'An ace caff with quite a nice museum attached'. For many curators in the museum, as well as observers outside of it, 'this advertisement was a blatant admission of the debasement of scholarship and the proper functions of the museum, and their subsumption to mere commercial and leisure interests' (Macdonald, 2002: 35). However, the V\&A was simply ahead of its time. Today, advertising by arts institutions is completely unremarkable, as it has become utterly common.

In addition to a focus on the marketable, arts institutions have moved from more elitist and scholarly aims to more populist and managerial ones, with more explicit agendas for inclusiveness and building audiences (Belfiore and Bennett, 2008) and more accountability through setting and meeting of targets and engaging in strategic and financial planning (Alexander, 2007). Changes are visible on the public-facing side of the institutionfor instance, a current exhibition at the V\&A is the popular exhibition Undressed: A Brief History of Underwear. ${ }^{13}$ The V\&A also runs the V\&A Innovative Leadership Programme, which helps participants to 'develop powerful tools for personal and professional growth', which is clearly different from a traditional museum course on art appreciation or crafting. ${ }^{14}$ Behind the scenes, the need for planning, marketing, and outreach changes the organizational structure of arts institutions and how artistic and professional careers work within them. The 
merits of these changes can be debated; however, the crucial point is that each of these activities represents an actual reduction in the autonomy of the sector as well as a weakening of the ideology of autonomy in the fine arts.

\section{Legitimacy, Neoliberalism, and the Supported Arts Sector}

The account given above suggests that changes are simply a matter of state power enacted through resource dependencies (Pfeffer and Salancik, 2003): arts organizations had become dependent on state funding, and as their need to retain access to these monies was stronger than their objections to the state's changed terms, arts organizations acquiesced to state demands. Similarly, as state funding was curtailed, corporate funds became a crucial resource, giving corporations power over arts institutions. Related to this is the idea of 'coercive isomorphism' (DiMaggio and Powell, 1983: 150), which 'results from both formal and informal pressures exerted on organizations by other organizations upon which they are dependent and by cultural expectations in the society within which organizations function.'

These 'simple' mechanisms may have profound consequences, however. In the US setting, DiMaggio (1991) argues that state and foundation funding exert coercive pressures that push towards a 'logic of access' (funders prefer larger audiences for various reasons) and a 'logic of accountability' (funders expect detailed financial reports). Similar arguments are made by Alexander (1996a), who also shows that the proportion of special exhibitions in American art galleries that have more popular formats and accessible content increases when galleries receive public and corporate funding. In the UK, the recent Conservative and Coalition governments have used the economic crisis as a justification for their main policy objective, which has been to enact neoliberal philosophy. Couching their ideological approach in economic terms makes it seem natural and inevitable (see Bourdieu and Wacquant, 2001). Arts organizations are not alone in being affected at a deep level, as their 
very practices as organizations reflect, and legitimate, the dominant ideology. It is worth considering how these resource dependencies in one field of action might work within the field of power, as part of a broader legitimation of neoliberal ideology in society.

\section{The Legitimacy of Neoliberalism}

In order to win government grants and to solicit corporate funds, arts institutions must speak the language of business (Hewison, 1995). To raise funds, then, arts institutions must woo funders on the funders' terms. Importantly, using certain terms (incorporating business buzz words in government grant applications, on web pages, or in pitches to corporations) or metrics (counting audience numbers, tracking revenue, or producing balanced account sheets) does not seem, on first glance, to change the art that is delivered. Funders do not seek to influence the 'content' of the arts. The changes they request, therefore, appear superficial and peripheral to the core 'business' of arts organizations. And yet, neoliberal interests penetrate these organizations through practices, perhaps even more deeply than they would if they focused on trying to influence content.

Neoliberal interests penetrate, in the first instance and as Bourdieu suggested, through language. For instance, it matters whether arts institutions speak of 'visitors' or 'customers'. Bourdieu warns, 'beware of words' (quoted in Wacquant, 1989: 54) as they 'import with them in an occult manner, a whole worldview constructed around historicized thinking; a kind of linguistic Trojan horse' (Grenfell, 2012: 251). ${ }^{15}$ Moreover, adopting neoliberal language is related to the reduction of autonomy, despite the fact that no state agency (or corporation) dictates what to display or perform, or proclaims what good art is. Looking for direct attacks on content misses the real issue in the hegemonic domination of arts organizations. The necessary changes, which may initially appear 'shallow', demonstrate a kind of acceptance of neoliberalism that showcases and legitimates this belief system. 
Further, people in the arts world do not need to take the ideology to heart, they just need to implement it in the practices of arts organizations. The state requires arts institutions to accept certain management tools and certain actions apparently at the surface level. The state does not compel individuals to believe in the neoliberal doctrine, just as it does not explicitly require particular kinds of artistic output. This apparently superficial change hides the very deep hegemonic domination of arts institutions. Many in the arts world strongly oppose neoliberal values (see Appleyard, 1984; Bourdieu and Haake, 1995; HooperGreenhill, 1988; Hewison, 1995; Osborne, 1986; West and Smith, 2005). Nevertheless, the dominant system gains symbolic capital from each strategy document, mission statement, and five-year plan produced in arts organizations. These provide evidence that the neoliberal model is correct, and that galleries, symphonies, opera, and dance and theatre companies should be managed like businesses, even if many of the artists, curators, musicians, composers, dancers, choreographers, actors, and playwrights might disagree.

Johnson, Dowd and Ridgeway (2006) suggest that legitimacy is a social process, with four stages, including 'innovation', 'local validation', 'diffusion', and 'general validation'. The UK supported arts sector was obviously not involved in the first two stages (innovation and local validation), which for neoliberalism have deep roots that can be traced back through the writings of Hayek (1994 [1944]) to the liberal philosophies of the nineteenth century. The more recent growth of neoliberalism has been international and diffuse (Evans and Sewell, 2013). The supported arts sector, however, is caught up in the diffusion process, which requires that the 'social object' (e.g. neoliberalism) be proliferated and translated into different parts of society. Thus, the diffusion of neoliberalism legitimates it.

Neoliberalism is profoundly legitimated by becoming embedded in arts organizations (and in homologous ways in other fields). The fact that arts institutions (just like charities, universities, or various public services) have adopted particular business practices suggests 
that this way of organizing is, at the minimum, a very sensible way to organize, or taken further, that it is the natural, inevitable way of doing so, the only possible way to think about human endeavour. With the widespread use of neoliberal rationality, other forms of rationality are weakened or closed down.

\section{Changing Fields of Power}

The contemporary state and the dominant classes associated with it have changed, and this affects the way legitimating processes work in the supported arts sector. Previously, elites supported prestigious art works and arts institutions (with the prestige reflecting back through the 'halo effect'). Now, they legitimate the business-centred approaches they favour by changing the practices of arts institutions. Believing, and wanting others to believe, that business rationality, a consumer orientation, and self-support through earned income and grant-getting are the best way to run non-profit organizations, these elites press arts organizations to adopt these practices. And in achieving this, elites naturalize the neoliberal model and discredit alternative ways of operating non-profits.

Thatcherism was the British manifestation of a world-wide restructuring of capitalism which, among other things, empowered a financial elite over other elite orders, such as those rooted in aristocracy (Evans and Sewell, 2013). Thus, a change in the field of power has affected arts institutions, which in the 1940s had enhanced the cultural and symbolic capital of intellectual elites like Lord Keynes. From 1979 arts institutions also, if reluctantly, enhanced the legitimacy of financial elites and their political allies through their acceptance of neoliberal ideology. In the past, artists have flattered their patrons with compliments, beneficial portrayals, or inclusion in the artwork. Now the practices through which arts organizations operate flatter the ideology of the patrons. 


\section{'The Scourge of Neoliberalism'}

Bourdieu wrote passionately about the 'scourge of neoliberalism' (Bourdieu, 1998b: vii). His reflections on the topic are scattered across his writings, but he wrote explicitly about the effect of neoliberalism on culture (1998b; 2003). His focus in these comments was on publishing and cinema, rather than the fine arts. He also continued to emphasise the threat from commercial influence. In Acts of Resistance, Bourdieu wrote about an anxious insecurity in Britain and France made worse by a threat to the arts:

Added to this, at the present time, is the destruction of the economic and social bases of the most precious cultural gains of humanity. The autonomy of the worlds of cultural production with respect to the market, which had grown steadily through the battles and sacrifices of writers, artists and scientists, is increasingly threatened. The reign of 'commerce' and the 'commercial' bears down more strongly every day on literature, particularly through the concentration of publishing, which is more and more subject to the constraints of immediate profit; on literary and artistic criticism, which has been handed over to the most opportunistic servants of the publishers...; and especially on the cinema... Not to mention the social sciences, which are condemned either to subordinate themselves to the directly self-interested sponsorship of corporate or state bureaucracies or wither under the censorship of power ... or money. (1998b p. 37-8)

He expanded on these comments in 'Culture is in Danger', a chapter in Firing Back. He writes, 'What is at stake here is the perpetuation of a cultural production that is not oriented toward exclusively commercial ends and is not subject to the verdicts of those who dominate mass media production' (2003: 70). 
Bourdieu (1998b: 25) writes, the 'state nobility, which preaches the withering away of the state and the undivided reign of the market and the consumer, the commercial substitute for the citizen, has kidnapped the state: it has made the public good a private good.' Here, Bourdieu's words highlight an irony in the observation that the UK supported arts sector has become more heteronomous with the state. This is not an argument about the influence of the 'Big State' of welfare capitalism, which the political right argues needs to be dismantled. That political system supported an autonomous field of cultural production. Instead, it is the right's 'small', noninterventionist state that is doing the interpenetrating. ${ }^{16}$

Of course, the fine arts in the supported arts sector have never been truly autonomous; they have been closer to Bourdieu's (1993) idea of 'Bourgeois' art, given that they have attracted privileged and, more recently, middle-class patrons and audiences. However, they were part of 'legitimate culture' (Bourdieu, 1984), as consumption of the fine arts represented a status claim for 'the establishment'. Despite these complexities, a strong belief that art should be autonomous and should be protected from interference has obtained for the last 150 years or so. The cultural and symbolic capital of elites who consumed it depended on this, and in later work, Bourdieu argued that the ideology of autonomy was a worthy achievement. A new dominant order has emerged, however. Art and culture matter less, and profits and wealth matter more, as cultural capital appears to be displayed not in taste for the fine arts, but in taste for consumer goods and experiences such as dining out or travelling.

\section{Homologies across Fields}

Throughout his work, Bourdieu argued that different fields situated within the 'field of power' are homologous due to the structuring influence of the overarching field of power. As Jenkins (1992: 86) put it, the homologies among fields, or 'the resemblance which is bound up with difference', is 'a consequence of the power of dominant fields, particularly the 
field of power (politics), to impinge upon weaker fields and structure what occurs in them.' However, as Thomson (2012: 78) wrote:

Bourdieu is unequivocal that some fields are dominant and others subordinate, but it is not necessarily clear how this domination is materially enacted... Bourdieu argued that the interrelationships of fields were specific and not amenable to a universal theory.

I have suggested that state funding, via resource dependencies and coercive pressures, is one way in which neoliberalism was insinuated into arts organizations in the supported arts sector. However, this may be only one of several mechanisms by which the interrelationships between the political and commercial fields and other fields occur, and homologies across fields may be created in a variety of ways.

The field structures of many types of arts institutions, such as museums (Grenfell and Hardy, 2007), contain significant homologies across national contexts, and may be similarly homologous with respect to the penetration of neoliberal ideology. As with arts institutions in the UK, arts institutions in other countries appear to face pressures from neoliberal states and from the commercial sector. In continental Europe, funding for arts institutions was privatized (devolving from state-centred funding to a mixed arrangement of public and private funds) to conform more closely to what is called the 'American model' (Boorsma et al., 1998), and these institutions were required to contribute to non-arts policy outcomes (Gray, 2007). The precise nature of the interpenetration of fine arts institutions with the neoliberal state, however, may vary across national contexts.

For instance, in America, arts controversies appear to be a major component in the relationship between American arts institutions and the state (Dubin, 1992; Kidd, 2012; 
Rothfield; 2001; Shockley and McNeely, 2009). And while corporate and government funding have changed exhibitions in American arts organizations (Alexander, $1996 \mathrm{a}, \mathrm{b}$ ), US corporate funding arrived in the arts as part of a larger, deeply embedded philanthropic culture. In contrast, in the UK (and elsewhere) corporate sponsorship was specifically encouraged by the state.

Another useful comparison to the UK supported arts sector is higher education. In the cultural arena more broadly, the neoliberal university has become familiar both in the UK (Collini, 2012; Gill, 2010; Monbiot, 2000: Ch. 9; Smith, 2010; 2012) and the US (Espeland and Sauder, 2007; Readings, 1996; Tuchman, 2009). Detailed analysis may show the levels, effects, and mechanisms whereby the state or neoliberalism influences this sector in various national contexts.

\section{Conclusion}

This paper has two interrelated aims. First, to consider that neoliberalism penetrates spheres where alternative philosophies had previously flourished. And second, to use Bourdieu's notion of fields and autonomy/heteronomy to understand the relationship among fields, expanding it to suggest heteronomy in cultural spheres can come not only from the commercial but from the political field.

I have provided one explanation of how the state and its current philosophy, neoliberalism, gets into the field of cultural production. This occurs through a Faustian bargain, in the medium of funding, with resulting resource dependencies and coercive pressures. Importantly, neoliberalism penetrates arts institutions apparently on the surface level, but the superficial changes needed to fit an art gallery or an opera company to the neoliberal state have profound consequences. The apparent superficiality reduces resistance at the same time as it legitimates the neoliberal philosophy through the diffusion of its 
practices. And enacting neoliberal practices through funding and operations management, changes arts institutions, moving them away from a more autonomous realm focused on the intrinsic merits of the arts to a heteronomous realm where customers, marketing and financial planning are 'naturally' more important.

The increasing ascendance of neoliberalism and its intrusion into spaces where markets had been weak or absent — the arts, universities, charities, the professions, social services, health care, among others, in the UK and internationally—suggests that neoliberalism represents something new, signalling a significant change in the relations among fields. Indeed, its rise is possibly the most important and consequential ideological developments of our era. Consequently, understanding how it gains legitimacy by making its core practices seem inevitable, especially in previously autonomous arenas, is a vital task for the 21 st century.

\section{Notes:}

\footnotetext{
${ }^{1}$ I would like to thank (in alphabetical order) Sara Arber, Jim Benson, Anne Bowler, Martin Bulmer, Geoff Cooper, Charlie Masqualier, Erkki Sevänen, and Vera Zolberg for support and comments on earlier drafts, as well as the anonymous reviewers for useful suggestions.

${ }^{2}$ To be clear, I refer to art galleries in the British sense of the term to indicate public or nonprofit museums that display art. I do not discuss commercial art galleries (dealerships) in this paper.

${ }^{3}$ Each of these terms suggests a somewhat different subset of changes. More generally, terms such as ‘commercialization', or 'Disneyfication' (Zukin, 1996) and 'Disneyization' (Bryman, 2004), as well as 'McDonaldization' (Ritzer, 1993), describe aspects of similar trends (very loosely conceived) in various fields. It is not the project of this article to disentangle the
} 
complexities of these terms, but rather to examine how funding imposes the set of processes they describe on arts organizations.

${ }^{4}$ It is not clear what terms differentiate a larger, more encompassing 'field' from a smaller, subsumed, one, or when the term 'subfield' is preferable. Bourdieu talked about fields within fields (e.g. 1993: 37-8), but also about 'sectors' (e.g. 1993: 39) or 'poles' (e.g. 1993: 40) within a field.

${ }^{5}$ For a discussion of the history of state funding of the arts in the UK, see, amongst others, Minihan (1977), Pearson (1982), Alexander (2007, 2008), Alexander and Rueschemeyer (2005), Gray (2000), Hewison (1995), Pick, (1991), Upchurch (2004), and Wu (2002).

${ }^{6}$ For overviews of Thatcher's policies towards the arts, see Alexander and Rueschemeyer (2005), Beck (1989), Bennett (1995), Hewison (1995), Gray (2000), and Wu (2002).

${ }^{7}$ For discussions of cultural policies after Thatcher, see Alexander $(2007 ; 2008 ; 2014)$, Belfiore (2002; 2004; 2009; 2012), Gray (2008), O’Brien (2014).

${ }^{8}$ On the lack of evidence that the arts foster social inclusion, see Belfiore and Bennett (2008).

${ }^{9}$ Philanthropy has also been captured by market ideology, in the new 'philanthrocapitalism' (Bishop and Green, 2008).

${ }^{10}$ This paper does not consider Theresa May's government.

${ }^{11}$ Of course, these broad-brush explanations conceal complexity, such as divisions within museums (Rees Leahy, 2007; Zolberg, 1986) and debates within the field (Gibson, 2008; O'Neill, 2008). It is beyond the scope of this paper to discuss how different factions or people within specific cultural organizations reacted to government policies, or how cultural policy is itself a partially unintended 'resultant' of complex actions of many parties (c.f. Allison and Zelikow, 1999).

${ }^{12}$ And in terms of effects on artists and art itself, McGuigan (2016) suggests that Damien Hirst is the contemporary neoliberal artist par excellence, who has been able to capitalize on 
his brand to become a rich man (see also Thompson, 2008). While not disagreeing with this assessment per se, the neoliberal penetration of arts institutions means that such institutions are more likely to showcase well-known artists with broad appeal, focusing on the popular, conventional and well-known, rather than the esoteric, little-known, forgotten or experimental. In the visual arts, this includes Monet, Van Gogh, Rembrandt, Matisse and other great artists who are also household names. In classical music, this would be Bach, Beethoven and Brahms - but also famous (or sometimes unnamed) composers of pop music or television theme songs, renditions of which are played by a symphony at the Proms. ${ }^{13}$ In October 2016, the V\&A hosted four special exhibitions: Undressed, as mentioned, as well as You Say You Want a Revolution? Records and Rebels 1966-1970, Engineering the World: Ove Arup and the Philosophy of Total Design, and Opus Anglicanum: Masterpieces of English Medieval Embroidery. The first two are quite clearly pitched to a popular audience. The second two may focus on more scholarly topics, but to be sure, they are beautifully designed and packaged with accessible descriptions and supporting material. The V\&A is not alone in this, and examples of similar activities are readily available on the home pages of arts institutions across all disciplines.

${ }^{14}$ See https://www.vam.ac.uk/info/va-innovative-leadership-programme. The programme description also states, 'You will explore how to apply your passion and creativity to the practicalities of leading in an ever-changing and increasingly complex world and how to lead innovatively in the creative industries.'

${ }^{15}$ For an excellent analysis of the language used by Tony Blair's New Labour, see Fairclough (2000).

${ }^{16}$ Centeno and Cohen (2012: 325) noted, the 'smaller' state did not actually materialise; globally, states did not shrink very much. Indeed, they write, 'The centrality of politics belies the contention that neoliberalism was antistatist' (p. 325). 


\section{Bibliography:}

Allison, G.T. and Zelikow, P. 1999 Essence of Decision: Explaining the Cuban Missile Crisis, second edition, New York: Addison-Wesley Longman.

Alexander, V.D. 1996a 'Pictures at an Exhibition: Conflicting Pressures in Museums and the Display of Art,' American Journal of Sociology, 101(4): 797-839.

Alexander, V.D. 1996b 'From Philanthropy to Funding: The Effects of Corporate and Public Support on American Art Museums,' Poetics, 24(2-4): 89-131.

Alexander, V.D. 1999 'A Delicate Balance: Museums and the Market-place,' Museum International, 51(2): 29-34.

Alexander, V.D. 2007. 'State Support of Artists: The Case of the UK in a New Labour Environment and Beyond,' Journal of Arts Management, Law and Society, 37(3): 185-200. Alexander, V.D. 2008 'Cultural Organizations and the State: Art and State Support in Contemporary Britain', Sociology Compass 2(5): 1416-30.

Alexander, V.D. 2014 'Art and the Twenty-First Century Gift: Corporate Philanthropy and Government Funding in the Cultural Sector', Anthropological Forum, 24(4): 364-380.

Alexander, V.D., Hägg, S., Häyrynen, S., and Sevänen, E. (eds.) Forthcoming. Art and the Challenge of Markets, Volume 1: National Cultural Politics and the Challenges of Marketization and Globalization, London: Palgrave.

Alexander, V.D. and Rueschemeyer, M. 2005 Art and the State: The Visual Arts in Comparative Perspective, London: Palgrave.

Appleyard, B. 1984 The Culture Club: Crisis in the Arts, London: Faber and Faber. Ballé, C. 2002 'Democratization and Institutional Change: A Challenge for Modern Museums', in D. Crane, N. Kawashima and K. Kawasaki (eds) Global Culture: Media, Arts, Policy, and Globalization, London: Routledge, pp. 132-45. 
Beck, A. 1989 'The Impact of Thatcherism on the Arts Council', Parliamentary Affairs, 43(3): $362-79$.

Belfiore, E. 2002 'Art as a Means of Alleviating Social Exclusion: Does It Really Work? A Critique of Instrumental Cultural Policies and Social Impact Studies in the UK', International Journal of Cultural Policy, 8(1): 91-106.

Belfiore, E. 2004 'Auditing Culture', International Journal of Cultural Policy, 10(2): 183202.

Belfiore, E. 2009 'On Bullshit in Cultural Policy Practice and Research: Notes from the British case', International Journal of Cultural Policy, 15(3): 343-359.

Belfiore, E. 2012 “"Defensive Instrumentalism” and the Legacy of New Labour's Cultural Policies', Cultural Trends, 21(2); 103-11.

Belfiore, E. and Bennett, O. 2008 The Social Impact of the Arts: An Intellectual History, New York: Palgrave Macmillan.

Bennett, O. 1995 'Cultural Policy in the United Kingdom: Collapsing Rationales and the End of a Tradition', International Journal of Cultural Policy, 1(2): 199-216.

Bishop, M. and Green, M. 2008 Philanthrocapitalism, London: A\&C Black.

Boorsma, P.B., van Hemel, A., and van der Wielen, N. (eds) 1998 Privatization and Culture: Experiences in the Arts, Heritage and Cultural Industries in Europe, London: Kluwer.

Bourdieu, P. 1984 Distinction: A Social Critique of the Judgement of Taste, Cambridge: Harvard University Press.

Bourdieu, P. 1990 The Logic of Practice, Cambridge: Polity.

Bourdieu, P. 1993 The Field of Cultural Production, Cambridge: Polity.

Bourdieu, P. 1995 The Social Structures of the Economy, Cambridge: Polity. 
Bourdieu, P. 1996a The Rules of Art: The Genesis and Structure of the Literary Field, Stanford: Stanford University Press.

Bourdieu, P. 1996b The State Nobility: Elite Schools in the Field of Power, Cambridge: Polity.

Bourdieu, P. 1998a Practical Reason: On the Theory of Action, Cambridge: Polity.

Bourdieu, P. 1998b Acts of Resistance: Against the New Myths of Our Time, Oxford: Polity.

Bourdieu, P. 2003 Firing Back: Against the Tyranny of the Market 2, London: New Press.

Bourdieu, P. and Haake, H. 1995 Free Exchange, Oxford: Polity.

Bourdieu, P. and Wacquant, L. 1999 'On the Cunning of Imperialist Reason', Theory, Culture \& Society, 16(1): 41-58.

Bourdieu, P. and Wacquant, L. 2001 'NewLiberalSpeak: Notes on the New Planetary Vulgate', Radical Philosophy, 105: 2-5.

Bryman, A.E. 2004 The Disneyization of Society, London: Sage.

Cabinet Office 2010 Giving: Green paper, London: HM Government.

Centeno, M.A. and Cohen, J.N. 2012 'The Arc of Neoliberalism', Annual Review of Sociology, 38: 317-40.

Chang, H.J. 201023 Things They Don't Tell You About Capitalism, London: Penguin. Collini, S. 2012 What Are Universities For? London: Penguin.

Crouch, C. 2011 The Strange Non-Death of Neoliberalism, Cambridge: Polity.

DiMaggio, P. 1982a 'Cultural Entrepreneurship in Nineteenth-Century Boston: The Creation of an Organizational Base for High Culture in America', Media, Culture and Society, 4: 3350.

DiMaggio, P. 1982b 'Cultural Entrepreneurship in Nineteenth-Century Boston, Part II: The Classification and Framing of American Art', Media, Culture and Society, 4: 303-22.

DiMaggio, P. 1987 'Classification in Art', American Sociological Review, 52: 440-455. 
DiMaggio, P. 1991 'Social Structure, Institutions and Cultural Goods: The Case of the United States', in P. Bourdieu and J.S. Coleman (eds) Social Theory for a Changing Society, Boulder: Westview Press, pp. 133-55.

DiMaggio, P. J., and Powell, W.W. 1983 'The Iron Cage Revisited: Institutional Isomorphism and Collective Rationality in Organizational Fields', American Sociological Review, 48: 147-60.

Dubin, S.C. 1992 Arresting Images: Impolitic Art and Uncivil Actions, New York: Routledge.

Espeland, W.N. and Sauder, M. 2007 'Rankings and Reactivity: How Public Measures Recreate Social Worlds', American Journal of Sociology, 113(1): 1-40.

Evans, P.B. and Sewell, W.H. Jnr 2013 'Neoliberalism: Policy Regimes, International Regimes, and Social Effects', in P.A. Hall and M. Lamont (eds.), Social Resilience in the Neoliberal Era. New York: Cambridge University Press, pp. 35-68.

Fairclough, N. 2000 New Labour, New Language? London: Routledge.

Frank, T. 2000 One Market Under God: Extreme Capitalism, Market Populism, and the End of Economic Democracy, New York: Anchor Books.

Gibson, L. 2008 'In defence of instrumentality', Cultural Trends, 17(4): 247-57.

Gill, R. 2010 'Breaking the Silence: The Hidden Injuries of the Neoliberal University', in R. Gill and R. Ryan-Flood, (eds), Secrecy and Silence in the Research Process: Feminist Reflections, London: Routledge, pp. 228-44.

Gray, C. 2000 The Politics of the Arts in Britain, London: Macmillan.

Gray, C. 2007 'Commodification and Instrumentality in Cultural Policy’, International Journal of Cultural Policy, 13(2): 203-15.

Gray, C. 2008 'Instrumental Policies: Causes, Consequences, Museums and Galleries’, Cultural Trends, 17(4): 209-22. 
Grenfell, M. 2012 'Politics', in M. Grenfell (ed.) Pierre Bourdieu: Key Concepts, second edition, Durham: Acumen, pp. 250-64.

Grenfell, M. and Hardy, C. 2007 Art Rules: Pierre Bourdieu and the Visual Arts, Oxford:

Berg.

Harrison, S. and Dowswell, G. 2002 'Autonomy and Bureaucratic Accountability in Primary Care: What English General Practitioners Say', Sociology of Health \& Illness, 24(2): 208-26.

Harvey, D. 2005 A Brief History of Neoliberalism, Oxford: Oxford University Press. Heelas, P and Morris, P (eds) 1992 The Values of the Enterprise Culture: The Moral Debate, London: Routledge.

Hewison, R. 1995 Culture and Consensus: England, Art and Politics since 1940, London: Methuen.

Hooper-Greenhill, E. 1988 ‘Counting Visitors or Visitors Who Count?’ in R. Lumley (ed.), The Museum Time Machine, London: Routledge, pp. 211-32.

Hayek, F.A. 1994 [1944] The Road to Serfdom, Chicago: University of Chicago Press. Jenkins, R. 1992 Pierre Bourdieu, London: Routledge.

Johnson, C., Dowd, T.J. and Ridgeway C.L. 2006 'Legitimacy as a Social Process', Annual Review of Sociology, 32: 53-78.

Johnson, R. 1993 'Editor's Introduction: Pierre Bourdieu on Art, Literature and Culture', in P. Bourdieu, The Field of Cultural Production, Oxford: Polity, pp. 1-25.

Kidd, D. 2012 'Fire in Our Bellies, Fear in Our Arts', Contexts, 11: 54-5.

Krause, E.A. 1996 Death of the Guilds: Professions, States and the Advance of Capitalism, 1930 to the Present, New Haven: Yale University Press.

Levine, L.W. 1988 Highbrow, Lowbrow: The Emergence of a Cultural Hierarchy in America, Cambridge: Harvard University Press. 
Macdonald, S. (2002). Behind the Scenes at the Science Museum. Oxford: Berg.

McCarthy, K.F., Ondaatje, E.H., Zakaras, L, Brooks, A. 2004 Gifts of the Muse:

Reframing the Debate about the Benefits of the Arts, Santa Monica: RAND Corporation.

McGuigan, J. 2005 'Neo-Liberalism, Culture and Policy', International Journal of Cultural Policy, 11(3): 229-41.

McGuigan, J. 2009 Cool Capitalism, London: Pluto Press.

McGuigan, J. 2016. Neoliberal Culture: London: Palgrave.

Mclean, F. 1997 Marketing the Museum, London: Routledge.

Minihan, J. 1977 The Nationalization of Culture: The Development of State Subsidies to the Arts in Great Britain, New York: New York University Press.

Monbiot, G. 2000 Captive State: The Corporate Takeover of Britain, London: Macmillan.

Mulcahy, K.V. 2004 ‘A Prolegomenon to Any Future Cultural Policy’, International

Conference on Cultural Policy Research, Montreal, Canada, August 25-28, 2004.

O’Brien, D. 2014 Cultural Policy: Management, Value and Modernity in the Creative Industries, London: Routledge.

O’Neill, M. 2008 'Museums, Professionalism and Democracy', Cultural Trends, 17(4): 289307.

Osborne, C. 1986 Giving it Away: Memoirs of a Uncivil Servant, London: Martin Secker \& Warburg.

Pearson, N.M. 1982 The State and the Visual Arts: A Discussion of State Intervention in the Visual Arts in Britain, 1760-1981, Milton Keynes: Open University Press.

Peterson, R.A. 1997 Creating Country Music: Fabricating Authenticity, Chicago: University of Chicago Press.

Pfeffer, J. and Salancik, G.R. 2003 The External Control of Organizations: A Resource Dependence Perspective, second edition, Stanford: Stanford University Press. 
Power, M. 1997 The Audit Society, Oxford: Oxford University Press.

Pick, J. 1991 Vile Jelly: The Birth, Life and Lingering Death of the Arts Council of Great Britain, Harleston, Norfolk: Brynmill Press.

Readings, B. 1996 The University in Ruins, Cambridge: Harvard University Press.

Rees Leahy, H. 2007 'New Labour, Old Masters’, Cultural Studies, 21(4-5): 695-717.

Ritzer, G. 1993 The McDonaldization of Society. Thousand Oaks: Pine Forge Press.

Rothfield, L. (ed.) 2001 Unsettling 'Sensation': Arts-Policy Lessons from the Brooklyn Museum of Art Controversy, New Brunswick: Rutgers University Press.

Sandell, R. and Janes, R.R. (eds) 2007 Museum Management and Marketing, London: Routledge.

Shockley, G. and McNeely, C.L. 2009 'A Seismic Shift in U.S. Federal Arts Policy: A Tale of Organizational Challenge and Controversy in the 1990s', The Journal of Arts Management, Law, and Society, 39(1); 7-23.

Smith, K. 2010 'Research, Policy and Funding: Academic Treadmills and the Squeeze on Intellectual Spaces', The British Journal of Sociology. 61(1): 176-95.

Smith, K. 2012 'Fools, Facilitators and Flexians: Academic Identities in Marketised Environments', Higher Education Quarterly, 66(2): 155-73.

Thompson, D. (2008). The \$12 Million Stuff Shark. London: Aurum.

Thomson, P. 2012 'Field', in M. Grenfell (ed.) Pierre Bourdieu: Key Concepts, second edition, Durham: Acumen, pp. 65-80.

Toepler, S. and Zimmer, A. 2002 'Subsidizing the Arts: Government and the Arts in Western Europe and the United States', in D. Crane, N. Kawashima and K. Kawasaki (eds) Global Culture: Media, Arts, Policy, and Globalization, London: Routledge, pp. 29-48. Trnka, S. and Trundle, C. 2014 'Competing Responsibilities: Moving beyond Neoliberal Responsibilisation', Anthropological Forum, 24(2): 136-53. 
Tuchman, G. 2009 Wannabe U: Inside the Corporate University. Chicago: University of Chicago Press.

Upchurch, A. 2004 'John Maynard Keynes, The Bloomsbury Group, and Origins of the Arts Council Movement', International Journal of Cultural Policy, 10(2): 203-17.

Wacquant, L.J.D. 1989 'Towards a Reflexive Sociology: A Workshop with Pierre Bourdieu', Sociological Theory, 7(1): 26-63.

West, C. and Smith, C.H.F. 2005 "We Are Not A Government Poodle": Museums and Social Inclusion under New Labour', International Journal of Cultural Policy, 11(3): 275-88.

Wu, C.T. 2002 Privatising Culture: Corporate Art Intervention since the 1980s, London: Verso.

Zolberg, V.L. 2000 'Privatization: Threat or Promise for the Arts and Humanities?' International Journal of Cultural Policy, 1(1): 1-19.

Zolberg, V.L. 1986 ‘Tensions of Mission in American Art Museums', in P. DiMaggio (ed.) Nonprofit Enterprise in the Arts: Studies in Mission and Constraint, New York: Oxford University Press, 184-98.

Zukin, S. 1996 The Cultures of Cities, Oxford: Blackwell. 